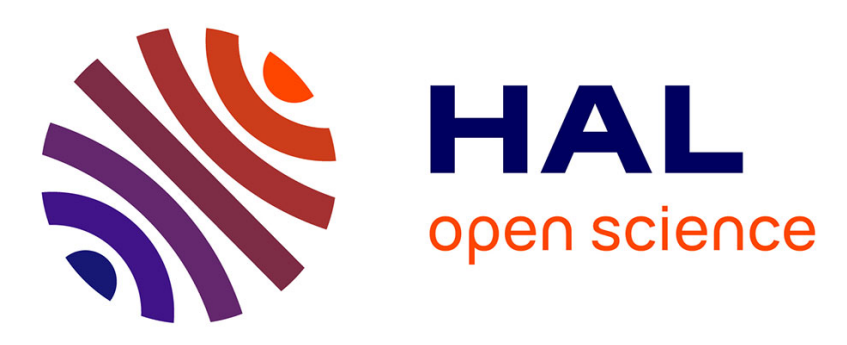

\title{
The effect of maternal linseed supplementation and/or lamb linseed supplementation on muscle and subcutaneous adipose tissue fatty acid composition of indoor lambs
}

\author{
Valérie Berthelot, Pierre P. Bas, E. E. Pottier, Jérôme J. Normand
}

\section{To cite this version:}

Valérie Berthelot, Pierre P. Bas, E. E. Pottier, Jérôme J. Normand. The effect of maternal linseed supplementation and/or lamb linseed supplementation on muscle and subcutaneous adipose tissue fatty acid composition of indoor lambs. Meat Science, 2012, 90 (3), pp.548-557. 10.1016/j.meatsci.2011.09.014 . hal-01000734

\section{HAL Id: hal-01000734 \\ https://hal.science/hal-01000734}

Submitted on 29 May 2020

HAL is a multi-disciplinary open access archive for the deposit and dissemination of scientific research documents, whether they are published or not. The documents may come from teaching and research institutions in France or abroad, or from public or private research centers.
L'archive ouverte pluridisciplinaire HAL, est destinée au dépôt et à la diffusion de documents scientifiques de niveau recherche, publiés ou non, émanant des établissements d'enseignement et de recherche français ou étrangers, des laboratoires publics ou privés. 
Provided for non-commercial research and education use. Not for reproduction, distribution or commercial use.

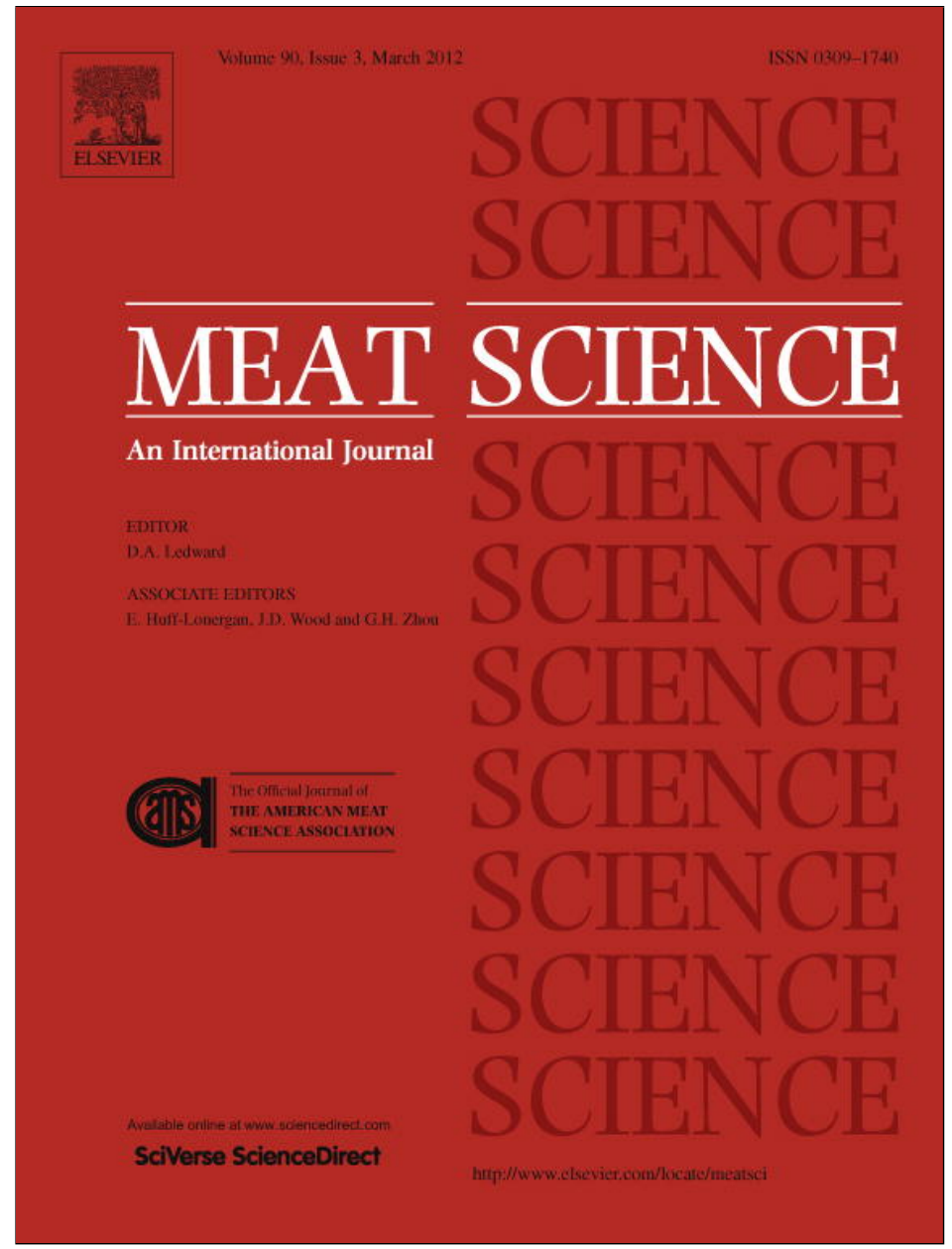

This article appeared in a journal published by Elsevier. The attached copy is furnished to the author for internal non-commercial research and education use, including for instruction at the authors institution and sharing with colleagues.

Other uses, including reproduction and distribution, or selling or licensing copies, or posting to personal, institutional or third party websites are prohibited.

In most cases authors are permitted to post their version of the article (e.g. in Word or Tex form) to their personal website or institutional repository. Authors requiring further information regarding Elsevier's archiving and manuscript policies are encouraged to visit:

http://www.elsevier.com/copyright 


\title{
The effect of maternal linseed supplementation and/or lamb linseed supplementation on muscle and subcutaneous adipose tissue fatty acid composition of indoor lambs
}

\author{
V. Berthelot ${ }^{\text {a,b,* }}$, P. Bas ${ }^{b}$, E. Pottier ${ }^{c}$, J. Normand ${ }^{d}$ \\ a AgroParisTech, Département de la Vie et Santé, 16 rue Claude Bernard, 75005 Paris, France \\ b INRA, UMR 791, Modélisation Systémique Appliquée aux Ruminants, 16 rue Claude Bernard, 75005 Paris, France \\ ${ }^{\mathrm{C}}$ Institut de l'Elevage-CIIRPO, Ferme expérimentale du Mourier, 87800 Saint Priest-Ligoure, France \\ d Institut de l'Elevage, Servie Oualité des Viandes, 23 rue Jean Baldassini, 69364 Lyon cedex 07, France
}

\section{A R T I C L E I N F O}

\section{Article history:}

Received 23 November 2010

Received in revised form 16 September 2011

Accepted 19 September 2011

\section{Keywords:}

Lamb

Muscle

Milk

Linseed

Polyunsaturated fatty acids

Softness index

\begin{abstract}
A B S T R A C T
Eighty eight lambs were used in a $2 \times 2$ factorial arrangement 1 ) to investigate the effect of maternal dietary linseed supplementation and/or lamb linseed supplemented concentrate on growth performance, carcass fat quality and fatty acid (FA) composition of muscle and dorsal adipose tissue of indoor lambs 2) to study the relationships between subcutaneous fat quality and FA composition. Feeding linseed to ewes increased C18:3 n-3 (ALA) proportion in milk and therefore the ALA supply to suckling lambs. However, ALA and n-3 polyunsaturated FA ( $n-3$ PUFA) proportions in lamb tissues were not affected. Feeding linseed to lambs during the post-weaning period significantly increased the proportions of ALA and n-3 PUFA in tissues. Softer and more colored fat was associated with a decrease in even medium-chain saturated FA and increases in odd and methyl FA proportions but not with ALA proportion in subcutaneous adipose tissue.
\end{abstract}

(c) 2011 Elsevier Ltd. All rights reserved.

\section{Introduction}

Consumer concerns about ruminant meat include a too high supply of fat, and fatty acid (FA) profiles that do not adequately meet human nutritional recommendations. Therefore, it has been recommended to decrease the proportions of saturated FA (SFA), increase the proportions of poly-unsaturated FA (PUFA), and especially of long-chain PUFA (LCFA) of the $n-3$ series in ruminant meat. These FA are targeted because of putative positive effects of these LCFA on cancer, atherosclerosis and coronary heart disease (Erkkilä, De Mello, Risérus, \& Laaksonen, 2008; Hooper et al., 2006; Leon et al., 2009). Moreover the proportion of trans-FA in meat, which results mostly from incomplete biohydrogenation of PUFA in the rumen, should be limited in meat due to their detrimental effects on human health (Willett \& Mozaffarian, 2008).

Several strategies have been studied to improve the nutritional value and n-3 PUFA content of intensively-reared lamb meat, mostly by incorporating linseed rich in C18:3 n-3 (ALA) in post-weaning diet (Bas, Berthelot, Pottier, \& Normand, 2007; Berthelot, Bas, \& Schmidely, 2010; Demirel et al., 2004; Wachira et al., 2002). Even

\footnotetext{
* Corresponding author at: UMR INRA-AgroParisTech 791, Modélisation Systémique Appliquée aux Ruminants, INRA-AgroParisTech, 16 rue Claude Bernard, 75005 Paris, France. Tel.: + 3301440818 86; fax: + 330144081853 .

E-mail address: valerie.berthelot@agroparistech.fr (V. Berthelot).
}

though PUFA undergoes high ruminal biohydrogenation (between $87 \%$ and $95 \%$ of the dietary intake) (Doreau \& Ferlay, 1993; Glasser, Schmidely, Sauvant, \& Doreau, 2008), lambs fed linseed during the post-weaning period had high muscle ALA content (in the range of 1.5 to $3 \%$ of total FA) and long-chain n-3 PUFA, C20:5 n-3 (EPA), C22:5 n-3 (DPA) or C22:6 n-3 (DHA) (Bas et al., 2007; Berthelot et al., 2010; Wachira et al., 2002). Pre-weaning, milk-fed lambs are considered as being "functional monogastrics" from a digestive point of view, as their reticular groove functionality prevents milk from passing into the rumen. Consequently, milk dietary PUFA can be efficiently transferred to tissues (Lanza et al., 2006). Therefore, over the whole period of lamb rearing, combining milk and postweaning diet enrichment with ALA could achieve a maximal deposition of n-3 PUFA in muscle and adipose tissues (AT). Recently, it has been shown that feeding a combination of soybean and marine algal oil in the pre-weaning diet (via supplementation of the ewe diet) and a combination of soybean and linseed oil in post-weaning lamb diets increased the PUFA content of the longissimus muscle and subcutaneous AT but without any increase in their ALA content (Radunz et al., 2009). However, lipids fed as oil more dramatically impair PUFA biohydrogenation than lipids fed as seeds, and that could have resulted in the higher trans-C18:1 content in muscle and fat tissues. Consequently, the effect of successive use of linseed in maternal and lamb concentrate on overall transfer of ALA to lamb muscle and AT needs to be studied.

Lamb meat rich in n-3 PUFA belongs to high quality trade markets in Europe. However, in order to meet the criteria for an economic 
premium, specifications are required on carcass characteristics and fat quality (firmness and color) that exclude carcasses with soft or yellow to brown-red colored AT (Aurousseau, 1999; Normand, Theriez, Bas, Aurousseau, \& Sauvant, 1999). Usually this AT problem is observed in intensively-reared male lambs fed high-grain diets that exhibit unusually high amounts of odd-numbered linear FA (Odd FA) and methyl-branched chain FA (BCFA) with low melting points (Gunstone, Harwood, \& Padley, 1994). These FA are mainly synthesized by microbes in the rumen (Vlaeminck et al., 2005) but in lambs some of these FA might also be synthesized de novo in subcutaneous AT. The unsaturated FA with 18 carbon atoms are also usually related to softness by decreasing the melting point of adipose tissue in lambs (Bas \& Morand-Fehr, 2000; L'Estrange \& Mulvihill, 1975). However as PUFA supplementation alters rumen microbial growth (Doreau \& Chilliard, 1997), tissue lipogenesis (Vernon, 1976) and tissue FA composition, feeding diets rich in ALA may alter Odd FA, BCFA and PUFA proportions in subcutaneous AT, and finally fat softness.

The aim of the present study was 1 ) to study the optimal combination of dietary linseed supplementation in maternal and/or lamb concentrates to maximally increase the n-3 PUFA proportion of muscle and AT and 2) to study the consequences of such dietary practices on the subcutaneous fat quality and its relationships to FA composition.

\section{Materials and methods}

\subsection{Experimental design, animals, and diets}

Sixty-four ewes and 88 lambs of the Vendeen sheep breed were used in this trial in order to investigate the effect of linseed supplementations in maternal and lamb concentrates in a $2 \times 2$ factorial design.

Three weeks after lambing, ewes and their respective lambs were blocked by rearing type (single, 10 ewes per group and twins, 6 ewes per group), sex of their lambs $(n=10-11$ male and $11-12$ female lambs per group) and weight of the litter. The ewes were fed forage (haylage during the first 4 weeks and hay for the last 4 weeks) and an ewe control (EC) or an ewe linseed (EL) concentrate for the control or linseed supplemented ewes respectively. One week after the start of the experiment and until slaughter, the lambs had free access to hay and a lamb control (LC) or a lamb linseed-supplemented (LL) concentrate for the control and the linseed supplemented lambs, respectively. The lambs of each group were weaned at eleven weeks of age and each group was transferred to a collective straw bedded pen. The lambs were slaughtered to obtain carcass weights around $18 \mathrm{~kg}$ for male lambs and around $16 \mathrm{~kg}$ for female lambs, and an optimum fat score of 3 according to the Ofival scale (1 to 5) (Council regulation EEC no. 2137/92).

The composition of the ewe and lamb concentrates are presented in Table 1. Linseed was supplied from Croquelin ${ }^{\circledR}$ (Valorex, Combourtouillé, France) which contains 50\% of extruded linseed, $30 \%$ of wheat bran and $20 \%$ of sunflower meal. The ewe concentrates had similar energetic and nitrogen values ( 0.88 Net Energy Unit for lactation (NEl)/kg according to the INRA system (1989) and 32.3\% CP), as well as the lamb concentrates ( $0.85 \mathrm{NE}$ for growth $/ \mathrm{kg}$ and $16.8 \% \mathrm{CP}$ ).

\subsection{Measurement and sampling}

Forages and concentrates distributed and refused were recorded weekly, for ewes and lambs, to determine their feed intake. Feed samples of each experimental diet were collected and stored at $-30{ }^{\circ} \mathrm{C}$ prior to analysis of chemical composition. Two weeks before weaning, 5 ewes per group were randomly chosen in each experimental group and milked once to determine milk FA composition. The milk samples were frozen at $-30{ }^{\circ} \mathrm{C}$ prior to milk FA analysis.
Table 1

The ingredient, chemical and fatty acid compositions of ewe control (EC) or linseed (EL) concentrates, lamb control (LC) or linseed (LL) concentrates.

\begin{tabular}{lllll}
\hline & EC & EL & LC & LL \\
\hline Concentrate composition (\%) & & & & \\
Triticale & 12.2 & - & 15.0 & 15.0 \\
Wheat & - & - & 10.0 & 10.0 \\
Barley & - & - & 25.0 & 19.5 \\
Croquelin ${ }^{\text {a }}$ & - & 25.0 & - & 12.0 \\
Extruded soybean & 12.0 & - & - & - \\
Soybean meal & 54.9 & 45.0 & 12.0 & 6.3 \\
Rapeseed meal & 5.0 & 10.0 & 8.0 & 8.0 \\
Groundnut meal & - & 4.0 & - & - \\
Sunflower meal & - & 0.7 & - & 2.2 \\
Calcium salt of palm oil & 0.5 & - & 0.5 & - \\
Molasses & 6.0 & 6.0 & 4.0 & 4.0 \\
Wheat bran & - & - & 4.6 & 12.0 \\
Dehydrated sugar beet pulp & - & - & 17.4 & 7.0 \\
Minerals and vitamins mixture & 9.4 & 9.3 & 3.5 & 4.0 \\
& & & & \\
Chemical composition (\% DM) & & & & \\
DM & 86.8 & 87.4 & 87.1 & 86.8 \\
OM & 87.7 & 86.2 & 91.4 & 91.3 \\
Crude protein & 37.7 & 36.5 & 19.1 & 19.6 \\
Ether extract & 5.4 & 7.5 & 2.9 & 5.3 \\
Starch & 13.1 & 6.1 & 38.8 & 33.8 \\
& & & & \\
Fatty acid g/kg DM & & & & \\
C16:0 & 6.5 & 5.9 & 5.0 & 5.0 \\
C18:0 & 2.2 & 2.5 & 0.7 & 1.2 \\
C18:1 n-9 & 12.1 & 16.0 & 6.3 & 11.4 \\
C18:3 n-3 & 27.9 & 16.0 & 14.3 & 15.7 \\
\hline & 4.3 & 34.0 & 1.7 & 18.4 \\
\hline
\end{tabular}

${ }^{\mathrm{a}}$ Croquelin ${ }^{\circledR}=50 \%$ extruded linseed, $30 \%$ wheat bran, $20 \%$ sunflower meal.

Lambs were weighed at the beginning of the experiment, at weaning and just before slaughter to determine their ADG. All data presented will be on male lambs as muscle FA composition was determined on males. After slaughter, cold carcasses were weighted after a period of 18 -h of cooling-off and drying out at $3^{\circ} \mathrm{C}$. Conformation score $\left(\mathrm{P}^{-}=1\right.$ to $\left.\mathrm{E}^{+}=15\right)$ and fatness score $\left(1^{-}=1\right.$ to $\left.5^{+}=15\right)$ were estimated according to the EEC guidelines. The firmness and color of subcutaneous fat were judged on cooled carcasses according to the 4-point scale of the Institut de l'Elevage (1: very firm and white to 4: very soft, oily and colored; Normand et al., 1999). Fat color ( $L^{*}, a^{*}$, and $b^{*}$ values for measurements of lightness, degree of redness, and degree of yellowness, respectively) was also measured on the back fat (middle of the back near the last rib) using a CR-310 Minolta Colorimeter (Minolta Camera Company Ltd., Osaka, Japan). A dorsal subcutaneous adipose tissue sample was then removed and a sample of longissimus dorsi muscle (LD) was removed posterior to the 13th rib and trimmed of external fat. All samples were frozen at $-30{ }^{\circ} \mathrm{C}$ until freeze drying and $\mathrm{FA}$ analysis.

\subsection{Chemical analysis}

Dry matter (DM), ash, crude protein and enzymatic starch in feedstuffs were determined following the ISO standards 6496 (1999), 5984 (2002), 5983 (2005) and 15914 (2004) respectively. The lipid content of the diets was extracted according to Folch, Lees, and Stanley (1957).

Muscle and AT dry matter were determined after 48-h of freezedrying. FA content was determined by the method of Rule (1997), using heneicosanoic acid or tricosanoic acid as internal standard during extraction of FA from dorsal AT or muscle, respectively. Lipid extraction and methylation were described by Bas et al. (2007) for tissue samples and by de Andrade and Schmidely (2006) for milk. To determine the trans FA profile of milk and tissues, samples were injected with an autosampler CP-8410 into a Varian CP-3900 gas-chromatograph (Varian, Les Ulis, France) on a CP-SIL 88 fused silica capillary column 
(100-m L $\times 0.25-\mathrm{mm}$ i.d. $\times 0.20-\mu \mathrm{m}$ film thickness: Varian 3900, Les Ulis, France). FA were identified as described by Bas et al. (2007). To determine methyl branched-chain fatty acids and long-chain PUFA profile, tissue samples were run a second time on a DB-wax fused silica capillary column $(60-\mathrm{m} \mathrm{L} \times 0.25-\mathrm{mm}$ i.d. $\times 0.25-\mu \mathrm{m}$ film thickness: JW, Folsom, CA). All GC procedures are described in Berthelot et al. (2010). Methyl branched chain FA were identified from length equivalent chains (LEC, Miwa, Mikolajzack, Earle, \& Wolff, 1960) by interpolation between two consecutive saturated FA and compared to methyl ester standard mixtures (Sigma, St. Louis, MO) injected the same way for iso and anteiso-FA and FA previously identified by electron impact mass spectrometry for other methylbranched chain FA (OBCFA, Berthelot, Bas, Schmidely, \& DuvauxPonter, 2001; Berthelot, Normand, Bas, \& Kristensen, 2001; Normand, Bas, Berthelot, \& Sauvant, 2005). Proportions of C18:1 isomers separated on the CP-SIL column were determined in relation with the proportion of the C18:0 obtained on the DB-wax column. The FA are presented by families according to the structure (see tables footnotes). An index of the $\Delta-9$ desaturase activity was calculated on the conjugated linoleic acid (CLA) rumenic acid (C18:2 cis-9,trans-11; RA) according to Malau-Aduli, Siebert, Bottema, and Pitchford (1997) (IDCLA $=100 \times \mathrm{RA} /(\mathrm{VA}+\mathrm{RA}))$ with $\mathrm{VA}=$ vaccenic acid $=\mathrm{C} 18: 1$ trans -11 .

\subsection{Statistical analysis}

Feedlot performance, carcass quality and FA composition data were analyzed as a $2 \times 2$ factorial design using the PROC GLM procedure of SAS (2002). Pearson correlation coefficients between subcutaneous fat quality, lamb growth performance and FA composition in dorsal AT were calculated using the PROC CORR procedure. Relationships between growth performance, fat quality and FA composition in dorsal AT were qualitatively evaluated from principal component analysis (PCA) loading plots, based on the correlation matrix, using the PROC FACTOR procedure. Data in the text are presented as means \pm SEM unless stated. Significance was declared at $\mathrm{P}<0.05$.

\section{Results}

3.1. Ewe feed intake, milk FA composition and lamb growth performance before weaning

During the suckling period, average ewe forage intakes were 1.33 , $1.32,1.31$ and $1.34 \mathrm{~kg} \mathrm{DM} / \mathrm{ewe} /$ day and average ewe concentrate intakes were $0.37,0.37,0.33$ and $0.33 \mathrm{~kg} \mathrm{DM} / \mathrm{ewe} /$ day for the EC-LC, EC-LL, EL-LC and EL-LL groups respectively.

Short chain FA (C6:0 to $\mathrm{C} 10: 0)$, medium chain FA (C12:0 and $\mathrm{C} 14: 0$ ), Odd-FA, iso + anteiso-BCFA, and stearic acid proportions in milk were not affected by the ewe experimental concentrates (Table 2), whereas C16:0 $(\mathrm{P}<0.01)$ and $\mathrm{C16:1} \mathrm{n}-7(\mathrm{P}<0.01)$ proportions were lower in EL-LC and EL-LL ewe milk than in EC-LC and EC-LL ewe milk. Proportions of oleic acid (OLE), cis-C18:1 and trans-C18:1 isomers in milk were not affected by the ewe experimental concentrates. Compared to EC groups, LA milk proportion was lower $(\mathrm{P}<0.01)$, and ALA proportions were higher $(\mathrm{P}<0.001)$, in $\mathrm{EL}$ groups. The proportions of RA and C20:4 n-6 were not affected by the ewe experimental concentrates. There was a significant ewe concentrate $\times$ lamb concentrate interaction $(\mathrm{P}<0.05)$ for SFA and MUFA: compared to the other groups, the EC-LL group had the highest proportions of $\mathrm{C} 10: 0, \mathrm{C} 12: 0 \mathrm{C} 14: 0$, and the lowest proportions of $\mathrm{C} 17: 0, \mathrm{C} 18: 0$, OLE, VA and cis-C18:1 and trans-C18:1 in milk.

Before weaning, average lamb hay intakes were negligible (lower than $0.03 \mathrm{~kg} \mathrm{DM} / \mathrm{lamb} / \mathrm{day}$ ) and average lamb concentrate intakes were $0.17,0.25,0.27$ and $0.26 \mathrm{~kg} \mathrm{DM} / \mathrm{lamb} / \mathrm{day}$ for the EC-LC, EC-LL, EL-LC and EL-LL lambs respectively. The lamb weaning weights
Table 2

The effect of ewe linseed (EL) or control (EC) concentrates and lamb linseed (LL) or control (LC) concentrates on ewe milk fatty acid composition (\% of total FA).

\begin{tabular}{|c|c|c|c|c|c|c|c|c|}
\hline \multirow{2}{*}{$\frac{\text { Ewe diet }}{\text { Lamb diet }}$} & \multicolumn{2}{|l|}{ EC } & \multicolumn{2}{|l|}{ EL } & \multirow[t]{2}{*}{ SEM } & \multicolumn{3}{|l|}{$\mathrm{P}$} \\
\hline & LC & LL & LC & LL & & Ew & $\mathrm{La}$ & $\mathrm{Ew} \times \mathrm{La}$ \\
\hline C6:0 & 1.74 & 2.06 & 1.85 & 1.7 & 0.069 & 0.33 & 0.51 & 0.09 \\
\hline $\mathrm{C} 8: 0$ & 1.47 & 1.9 & 1.72 & 1.48 & 0.086 & 0.58 & 0.56 & 0.06 \\
\hline C10:0 & 4.15 & 6.03 & 5.2 & 4.24 & 0.314 & 0.51 & 0.41 & 0.02 \\
\hline $\mathrm{C} 12: 0$ & 2.49 & 3.41 & 3.24 & 2.65 & 0.148 & 0.98 & 0.51 & 0.008 \\
\hline $\mathrm{C} 14: 0$ & 8.48 & 10.5 & 10.5 & 9.24 & 0.302 & 0.47 & 0.41 & 0.004 \\
\hline C15:0 & 0.99 & 1.10 & 1.20 & 1.13 & 0.049 & 0.25 & 0.88 & 0.39 \\
\hline $\mathrm{C} 16: 0$ & 24.1 & 26.8 & 23.3 & 23.3 & 0.46 & 0.007 & 0.06 & 0.06 \\
\hline $\mathrm{C} 17: 0$ & 1.06 & 0.89 & 0.97 & 0.95 & 0.022 & 0.79 & 0.02 & 0.04 \\
\hline C18:0 & 13.4 & 11.4 & 12.8 & 13.4 & 0.33 & 0.25 & 0.20 & 0.03 \\
\hline C14:1 n-5 & 0.10 & 0.15 & 0.12 & 0.09 & 0.009 & 0.24 & 0.46 & 0.07 \\
\hline C16:1 n-7 & 0.95 & 1.03 & 0.80 & 0.80 & 0.040 & 0.01 & 0.56 & 0.51 \\
\hline C18:1 cis-9 & 26.0 & 21.5 & 23.1 & 24.9 & 0.73 & 0.87 & 0.32 & 0.03 \\
\hline C18: 1 trans-10 & 0.31 & 0.28 & 0.26 & 0.26 & 0.014 & 0.28 & 0.55 & 0.63 \\
\hline $\begin{array}{l}\text { C18:1 trans-11 } \\
\text { (VA) }\end{array}$ & 2.35 & 1.85 & 2.12 & 2.43 & 0.097 & 0.32 & 0.59 & 0.03 \\
\hline C18:2 n-6 (LA) & 1.84 & 1.71 & 1.56 & 1.52 & 0.044 & 0.004 & 0.23 & 0.53 \\
\hline C20:4 n-6 (ARA) & 0.07 & 0.07 & 0.08 & 0.08 & 0.004 & 0.80 & 0.90 & 0.85 \\
\hline $\begin{array}{l}\text { C18:2 cis-9, } \\
\text { trans-11 (RA) }\end{array}$ & 1.13 & 0.98 & 1.09 & 1.12 & 0.035 & 0.47 & 0.36 & 0.18 \\
\hline C18:3 n-3 (ALA) & 0.87 & 0.70 & 1.28 & 1.27 & 0.069 & $<0.001$ & 0.25 & 0.31 \\
\hline SFA & 58.7 & 65.0 & 61.7 & 59.1 & 0.888 & 0.33 & 0.22 & 0.006 \\
\hline Iso + anteiso-BCFA & 2.44 & 2.41 & 2.70 & 2.57 & 0.076 & 0.19 & 0.59 & 0.74 \\
\hline C18:1-cis & 26.5 & 22.0 & 23.6 & 25.4 & 0.744 & 0.86 & 0.31 & 0.03 \\
\hline C18:1-trans & 4.82 & 3.68 & 4.31 & 5.18 & 0.174 & 0.05 & 0.58 & 0.001 \\
\hline PUFA & 2.94 & 2.63 & 3.11 & 3.08 & 0.078 & 0.03 & 0.21 & 0.30 \\
\hline
\end{tabular}

$\mathrm{EW}=$ effect of the ewe concentrate, $\mathrm{La}=$ effect of the lamb concentrate

$\mathrm{SFA}=$ sum of even saturated FA (from C6:0 to C20:0) and of odd saturated FA (from C11:0 to C19:0) not included branched-chain FA (BCFA).

Iso + anteiso BCFA = methyl branched chain fatty acid of the iso and anteiso forms. C18: 1 -cis $=$ sum of cis C18:1 (cis-9 + cis- 11 to cis- 13 ).

C18:1-trans $=$ sum of trans C18:1 (trans- 6 to trans-16).

PUFA $=$ polyunsaturated fatty acid.

and their ADG before weaning were not affected by the experimental concentrates fed to the ewes or lambs (Table 3 ).

\subsection{Lamb feed intake, growth performance and carcass quality}

After weaning, the average hay intakes were $0.21,0.18,0.18$ and $0.19 \mathrm{~kg} \mathrm{DM} / \mathrm{lamb} /$ day and the average concentrate intakes were $0.84,0.99,1.03$ and $0.99 \mathrm{~kg} \mathrm{DM} / \mathrm{lamb} /$ day for EC-LC, EC-LL, EL-LC and EL-LL lambs respectively. Post-weaning ADG, age or weight at slaughter, cold carcass weight and killing out proportion (Table 3) were not affected by the experimental concentrates fed to the ewes or lambs. The conformation score was lower in EL-LC and EL-LL lambs than in EC-LC and EC-LL lambs, but no difference was observed for the fatness score. No difference in fat softness score, and in $\mathrm{b}^{*}$ value (yellowness), was observed between the 4 groups. However, the fat color score and $a^{*}$ value (redness) were higher in EC-LC lambs than in EC-LL whereas the $\mathrm{L}^{*}$ value (lightness) was lower, with EL-LC and EL-LL groups being intermediates.

\subsection{Fatty acid composition in muscle (Table 4) and dorsal adipose tissue (Table 5)}

Compared to the other groups, lambs from the EL-LL group had the highest proportion of VA $(\mathrm{P}<0.05)$ and the lowest proportion of OLE $(\mathrm{P}<0.05)$ in dorsal AT (Ewe Concentrate $\times$ Lamb Concentrate interaction). No other interaction was detected for individual FA or FA families in LD and dorsal AT. The ewe concentrate only modified ARA (C20:4 $n-6)$ proportions $(P=0.04)$ in lamb dorsal AT.

The DM and the proportions of FA, C14:0, C18:0, iso- and anteisoBCFA, and ESFA (even saturated FA) in LD were not affected by the experimental concentrates. Compared to lambs fed the LC concentrate, those fed the LL concentrate had lower proportions of C16:0 
Table 3

The effect of ewe linseed (EL) or control (EC) concentrates and lamb linseed (LL) or control (LC) concentrates on lamb growth performance and slaughter characteristics.

\begin{tabular}{|c|c|c|c|c|c|c|c|c|}
\hline \multirow{2}{*}{$\frac{\text { Ewe diet }}{\text { Lamb diet }}$} & \multicolumn{2}{|l|}{$\mathrm{EC}$} & \multicolumn{2}{|l|}{ EL } & \multirow[t]{2}{*}{ SEM } & \multicolumn{3}{|l|}{$\mathrm{P}$} \\
\hline & LC & LL & LC & LL & & Ew & La & $\mathrm{Ew} \times \mathrm{La}$ \\
\hline Number of lambs & 10 & 10 & 11 & 10 & & & & \\
\hline Weight at birth (kg) & 4.2 & 4.7 & 4.2 & 4.7 & 0.16 & 0.87 & 0.18 & 0.86 \\
\hline Weight at the beginning of the experiment $(\mathrm{kg})$ & 8.3 & 8.7 & 8.0 & 8.4 & 0.25 & 0.61 & 0.44 & 0.97 \\
\hline Age at the beginning of the experiment (d) & 21.8 & 20.5 & 20.9 & 20.2 & 0.31 & 0.32 & 0.11 & 0.62 \\
\hline Weight at weaning (kg) & 24.6 & 26.9 & 24.6 & 25 & 0.8 & 0.58 & 0.41 & 0.54 \\
\hline Age at weaning $(\mathrm{d})$ & 76.8 & 75.5 & 75.9 & 75.2 & 0.31 & 0.32 & 0.11 & 0.62 \\
\hline Weight at slaughter $(\mathrm{kg})$ & 39.5 & 38.6 & 39.5 & 38.9 & 0.27 & 0.81 & 0.16 & 0.72 \\
\hline Age at slaughter (d) & 118 & 112 & 118 & 117 & 3.05 & 0.67 & 0.57 & 0.68 \\
\hline ADG before weaning $(\mathrm{g} / \mathrm{d})$ & 262 & 294 & 268 & 268 & 10.6 & 0.63 & 0.47 & 0.45 \\
\hline ADG after weaning $(\mathrm{g} / \mathrm{d})$ & 401 & 402 & 368 & 373 & 16.1 & 0.52 & 0.98 & 0.74 \\
\hline Cold carcass weight (kg) & 18.2 & 18.4 & 18.3 & 17.9 & 0.16 & 0.58 & 0.73 & 0.46 \\
\hline Killing out proportion (\%) & 46.1 & 47.6 & 46.4 & 46.1 & 0.29 & 0.28 & 0.27 & 0.13 \\
\hline Conformation score ${ }^{1}$ & 9.8 & 9.3 & 8.7 & 8.7 & 0.20 & 0.04 & 0.51 & 0.55 \\
\hline Fatness score ${ }^{2}$ & 7.5 & 7.6 & 7.3 & 6.7 & 0.25 & 0.26 & 0.63 & 0.50 \\
\hline Fat softness score ${ }^{3}$ & 3.0 & 2.3 & 2.3 & 2.3 & 0.11 & 0.11 & 0.18 & 0.11 \\
\hline Fat color score ${ }^{4}$ & 3.2 & 1.9 & 2.5 & 2.2 & 0.16 & 0.48 & 0.01 & 0.07 \\
\hline \multicolumn{9}{|l|}{ Back fat colorimeter ${ }^{5}$} \\
\hline $\mathrm{L}^{*}$ & 69.3 & 75.1 & 71.7 & 71.1 & 0.70 & 0.53 & 0.05 & 0.02 \\
\hline$a^{*}$ & 12.5 & 9.1 & 10.6 & 11.1 & 0.39 & 0.88 & 0.05 & 0.01 \\
\hline $\mathrm{b}^{*}$ & 12.5 & 11.7 & 12.1 & 12.1 & 0.25 & 0.97 & 0.52 & 0.47 \\
\hline
\end{tabular}

Ew $=$ effect of the ewe concentrate, La $=$ effect of the lamb concentrate.

15 points conformation scale $\left(\mathrm{P}^{-}=1\right.$ to $\left.\mathrm{E}^{+}=15\right)$.

215 points fatness scale $\left(1^{-}=1\right.$ to $\left.5^{+}=15\right)$.

34 points scale: 1 : very firm to 4 : very soft and oily fat.

44 points scale: 1 : white to 4 : colored fat.

5 Color values measure: $\mathrm{L}^{*}=$ darkness to lightness, $\mathrm{a}^{*}=$ degree of redness, $\mathrm{b}^{*}=$ degree of yellowness

Table 4

The effect of ewe linseed (EL) or control (EC) concentrates and lamb linseed (LL) or control (LC) concentrates on Longissimus Dorsi fatty acid composition (\% of total fatty acid).

\begin{tabular}{|c|c|c|c|c|c|c|c|c|}
\hline \multirow{2}{*}{$\frac{\text { Ewe diet }}{\text { Lamb diet }}$} & \multicolumn{2}{|l|}{$\mathrm{EC}$} & \multicolumn{2}{|l|}{ EL } & \multirow[t]{2}{*}{ SEM } & \multicolumn{3}{|l|}{$\mathrm{P}$} \\
\hline & LC & LL & LC & LL & & Ew & $\mathrm{La}$ & $\mathrm{Ew} \times \mathrm{La}$ \\
\hline DM (\%) & 25.3 & 24.8 & 25.5 & 24.9 & 0.22 & 0.76 & 0.21 & 0.78 \\
\hline FA (\%) & 3.8 & 3.7 & 3.8 & 3.7 & 0.18 & 0.98 & 0.78 & 0.80 \\
\hline \multicolumn{9}{|l|}{ FA composition (\% total FA) } \\
\hline $\mathrm{C} 14: 0$ & 3.06 & 3.09 & 2.84 & 2.95 & 0.076 & 0.24 & 0.65 & 0.80 \\
\hline $\mathrm{C} 16: 0$ & 24.6 & 23.4 & 25.2 & 23.5 & 0.24 & 0.49 & 0.003 & 0.61 \\
\hline C18:0 & 14.0 & 13.6 & 14.1 & 15.1 & 0.28 & 0.15 & 0.63 & 0.19 \\
\hline C16:1 n-7 & 1.80 & 1.75 & 1.73 & 1.55 & 0.041 & 0.09 & 0.16 & 0.38 \\
\hline $\mathrm{C} 17: 1 \mathrm{n}-8$ & 0.650 & 0.560 & 0.610 & 0.530 & 0.0180 & 0.27 & 0.011 & 0.90 \\
\hline C18:1 cis-9 & 39.4 & 35.8 & 39.0 & 34.6 & 0.47 & 0.69 & $<0.001$ & 0.25 \\
\hline C18: 1 cis-11 & 1.030 & 0.960 & 1.080 & 1.040 & 0.0270 & 0.23 & 0.35 & 0.76 \\
\hline C18:1 trans- 10 & 1.51 & 1.44 & 1.37 & 1.44 & 0.136 & 0.79 & 0.99 & 0.81 \\
\hline C18:1 trans-11 (VA) & 1.81 & 2.53 & 1.52 & 3.35 & 0.189 & 0.39 & $<0.001$ & 0.08 \\
\hline C18:2 n-6 (LA) & 4.02 & 5.03 & 4.07 & 4.49 & 0.153 & 0.38 & 0.02 & 0.31 \\
\hline$C 18: 3 n-6$ & 0.052 & 0.044 & 0.049 & 0.032 & 0.0022 & 0.06 & 0.001 & 0.21 \\
\hline$C 20: 2 n-6$ & 0.048 & 0.061 & 0.046 & 0.056 & 0.0023 & 0.50 & 0.02 & 0.73 \\
\hline$C 20: 3 n-6$ & 0.11 & 0.10 & 0.11 & 0.09 & 0.005 & 0.75 & 0.15 & 0.50 \\
\hline C20:4 n-6 (ARA) & 0.83 & 0.79 & 0.90 & 0.72 & 0.041 & 0.98 & 0.18 & 0.37 \\
\hline $\mathrm{C} 22: 4 \mathrm{n}-6$ & 0.058 & 0.040 & 0.058 & 0.038 & 0.0027 & 0.67 & $<0.001$ & 0.99 \\
\hline C18:2 cis-9,trans-11 (RA) & 0.110 & 0.119 & 0.054 & 0.100 & 0.0107 & 0.07 & 0.18 & 0.38 \\
\hline C18: 2 trans- 10, cis- 12 & 0.055 & 0.065 & 0.041 & 0.062 & 0.0032 & 0.15 & 0.007 & 0.27 \\
\hline C18:3 n-3 (ALA) & 0.54 & 1.77 & 0.61 & 1.58 & 0.102 & 0.56 & $<0.001$ & 0.21 \\
\hline$C 20: 5 n-3(E P A)$ & 0.13 & 0.30 & 0.18 & 0.31 & 0.019 & 0.35 & $<0.001$ & 0.57 \\
\hline$C 22: 5 n-3$ & 0.24 & 0.36 & 0.27 & 0.35 & 0.018 & 0.75 & 0.004 & 0.54 \\
\hline $\mathrm{C} 22: 6$ n-3 (DHA) & 0.07 & 0.093 & 0.078 & 0.092 & 0.0060 & 0.87 & 0.18 & 0.84 \\
\hline iso + anteiso-BCFA & 1.46 & 1.33 & 1.28 & 1.36 & 0.030 & 0.20 & 0.67 & 0.10 \\
\hline Odd-FA & 2.29 & 2.02 & 2.14 & 2.09 & 0.041 & 0.61 & 0.05 & 0.16 \\
\hline ESFA & 42.2 & 40.6 & 42.6 & 42.0 & 0.31 & 0.13 & 0.07 & 0.34 \\
\hline MUFA & 45.5 & 43.4 & 45.3 & 42.3 & 0.35 & 0.84 & 0.004 & 0.88 \\
\hline PUFA & 6.3 & 8.8 & 6.5 & 8.0 & 0.29 & 0.50 & $<0.001$ & 0.28 \\
\hline n-6 PUFA & 5.11 & 6.05 & 5.22 & 5.42 & 0.181 & 0.92 & 0.11 & 0.39 \\
\hline n-3 PUFA & 0.98 & 2.53 & 1.13 & 2.34 & 0.133 & 0.89 & $<0.001$ & 0.27 \\
\hline C18:2 n-6/C18:3 n-3 & 7.96 & 2.99 & 6.97 & 2.89 & 0.407 & 0.14 & $<0.001$ & 0.23 \\
\hline
\end{tabular}

$\mathrm{Ew}=$ effect of the ewe concentrate, $\mathrm{La}=$ effect of the lamb concentrate.

$\mathrm{ESFA}=$ even-saturated fatty acids $=\mathrm{C} 12: 0+\mathrm{C} 14: 0+\mathrm{C} 16: 0+\mathrm{C} 18: 0+\mathrm{C} 20: 0$.

Odd-FA $=$ odd-saturated fatty acids $=\mathrm{C} 11: 0+\mathrm{C} 13: 0+\mathrm{C} 15: 0+\mathrm{C} 17: 0+\mathrm{C} 19: 0$.

MUFA $=$ monounsaturated fatty acids $=C 14: 1 \mathrm{n}-5+\mathrm{C} 16: 1 \mathrm{n}-7+\mathrm{C} 17: 1 \mathrm{n}-8+\Sigma \mathrm{C} 18: 1$.

$n-3$ PUFA $=\mathrm{C} 18: 3 \mathrm{n}-3+\mathrm{C} 20: 5 \mathrm{n}-3+\mathrm{C} 22: 5 \mathrm{n}-3+\mathrm{C} 22: 6 \mathrm{n}-3$

n-6 PUFA $=C 18: 2$ n-6 + C18:3 n-6 + C20:2 n-6 + C20:3 n-6 + C20:4 n-6 + C22:4 n-6.

PUFA $=$ polyunsaturated fatty acids $=n-3$ PUFA $+n-6$ PUFA.

Iso + anteiso BCFA $=$ methyl branched chain fatty acid of the iso and anteiso forms $=$ iso-C13:0 + iso-C14:0 + iso-C15:0 + anteiso-C15:0 + iso-C16:0 + iso-C17:0 + anteiso-C17:0 + iso-C18:0. 
Table 5

The effect of ewe linseed (EL) or control (EC) concentrates and lamb linseed (LL) or control (LC) concentrates on dorsal fatty acid composition (\% of total fatty acid).

\begin{tabular}{|c|c|c|c|c|c|c|c|c|}
\hline \multirow{2}{*}{$\frac{\text { Ewe diet }}{\text { Lamb diet }}$} & \multicolumn{2}{|l|}{ EC } & \multicolumn{2}{|l|}{$\mathrm{EL}$} & & \multicolumn{3}{|l|}{$P$} \\
\hline & LC & LL & LC & LL & & Ew & La & $\mathrm{Ew} \times \mathrm{La}$ \\
\hline $\mathrm{DM}(\%)$ & 74.1 & 77.3 & 76.9 & 78.4 & 0.79 & 0.29 & 0.18 & 0.62 \\
\hline \multicolumn{9}{|l|}{ FA composition (\% total FA) } \\
\hline $\mathrm{C} 14: 0$ & 3.05 & 3.46 & 3.20 & 3.02 & 0.148 & 0.62 & 0.71 & 0.32 \\
\hline $\mathrm{C} 15: 0$ & 0.95 & 0.74 & 1.14 & 0.87 & 0.052 & 0.10 & 0.02 & 0.72 \\
\hline $\mathrm{C} 16: 0$ & 20.1 & 19.6 & 20.9 & 18.7 & 0.34 & 0.97 & 0.04 & 0.19 \\
\hline $\mathrm{C} 17: 0$ & 2.33 & 1.77 & 2.61 & 2.08 & 0.118 & 0.18 & 0.02 & 0.96 \\
\hline C18:0 & 10.9 & 11.8 & 10.0 & 13.1 & 0.57 & 0.87 & 0.08 & 0.34 \\
\hline C16:1 n-7 & 2.14 & 1.83 & 2.22 & 1.59 & 0.073 & 0.52 & 0.001 & 0.22 \\
\hline $\mathrm{C} 17: 1 \mathrm{n}-8$ & 1.51 & 1.03 & 1.71 & 1.04 & 0.097 & 0.55 & 0.002 & 0.58 \\
\hline C18:1 cis-9 & 32.8 & 31.6 & 33.6 & 28.3 & 0.55 & 0.20 & 0.001 & 0.03 \\
\hline C18: 1 cis- 11 & 1.02 & 0.77 & 0.91 & 0.82 & 0.0318 & 0.69 & 0.01 & 0.16 \\
\hline C18:1 trans- 10 & 3.05 & 2.41 & 2.36 & 2.55 & 0.247 & 0.59 & 0.66 & 0.41 \\
\hline C18:1 trans-11 (VA) & 2.76 & 3.79 & 2.00 & 5.16 & 0.300 & 0.52 & $<0.001$ & 0.03 \\
\hline C18:2 n-6 (LA) & 3.17 & 3.58 & 2.86 & 3.52 & 0.118 & 0.41 & 0.02 & 0.56 \\
\hline C18:3 n-6 & 0.036 & 0.043 & 0.034 & 0.048 & 0.0018 & 0.73 & 0.001 & 0.28 \\
\hline C20:2 n-6 & 0.040 & 0.036 & 0.032 & 0.0 .32 & 0.0023 & 0.25 & 0.68 & 0.69 \\
\hline C20:4 n-6 (ARA) & 0.102 & 0.062 & 0.076 & 0.063 & 0.0038 & 0.04 & $<0.001$ & 0.03 \\
\hline C18:2 cis-9,trans-11 (RA) & 1.14 & 1.43 & 0.92 & 1.51 & 0.079 & 0.63 & 0.004 & 0.28 \\
\hline C18:2 trans- 10 ,cis- 12 & 0.024 & 0.021 & 0.016 & 0.023 & 0.0018 & 0.47 & 0.60 & 0.19 \\
\hline C18:3 n-3 (ALA) & 0.48 & 2.00 & 0.51 & 1.73 & 0.135 & 0.47 & $<0.001$ & 0.35 \\
\hline C20:5 n-3 (EPA) & 0.011 & 0.027 & 0.008 & 0.025 & 0.0019 & 0.33 & $<0.001$ & 0.83 \\
\hline $\mathrm{C} 22: 5 \mathrm{n}-3$ & 0.033 & 0.063 & 0.015 & 0.068 & 0.0074 & 0.60 & 0.004 & 0.39 \\
\hline iso-BCFA & 1.13 & 0.93 & 1.05 & 0.98 & 0.026 & 0.81 & 0.01 & 0.15 \\
\hline anteiso-BCFA & 1.60 & 1.07 & 1.44 & 1.23 & 0.052 & 0.99 & $<0.001$ & 0.06 \\
\hline OBCFA & 4.47 & 2.67 & 5.55 & 3.39 & 0.434 & 0.28 & 0.02 & 0.83 \\
\hline BCFA & 7.21 & 4.67 & 8.04 & 5.61 & 0.475 & 0.32 & 0.01 & 0.95 \\
\hline Odd-FA & 4.99 & 3.77 & 5.72 & 4.25 & 0.261 & 0.22 & 0.01 & 0.79 \\
\hline ESFA & 34.6 & 35.5 & 34.6 & 35.4 & 0.81 & 0.99 & 0.61 & 0.97 \\
\hline MUFA & 44.7 & 42.9 & 44.1 & 41.1 & 0.44 & 0.11 & 0.003 & 0.46 \\
\hline n-6 PUFA & 3.43 & 3.8 & 3.07 & 3.77 & 0.121 & 0.40 & 0.03 & 0.47 \\
\hline n-3 PUFA & 0.53 & 2.12 & 0.55 & 1.85 & 0.142 & 0.44 & $<0.001$ & 0.38 \\
\hline IDCLA & 31.1 & 27.5 & 33.6 & 23.8 & 1.090 & 0.75 & 0.001 & 0.11 \\
\hline
\end{tabular}

For most legends see Table 4.

OBCFA = methyl branched chain fatty acids other than the iso and anteiso forms.

BCFA $=$ iso-BCFA + anteiso-BCFA + OBCFA.

IDCLA $=$ one index of the $\Delta-9$ desaturase activity; $100 \times(R A /(V A+R A)$.

( $\mathrm{P}<0.01)$, Odd FA $(\mathrm{P}<0.05), \mathrm{C17}: 1(\mathrm{P}<0.05)$, oleic acid $(\mathrm{P}<0.001)$ and MUFA $(P<0.01)$, and higher proportions of VA $(P<0.001)$. No change in C18:1 trans-10 proportions was observed between the 4 groups. Compared to lambs fed the LC concentrate, those fed the LL concentrate had higher proportions of LA $(\mathrm{P}<0.05)$, C18:3 n-6 $(\mathrm{P}<0.001)$, $\mathrm{C} 20: 2$ n-6 $(\mathrm{P}<0.02)$, and $\mathrm{C} 18: 2$ trans-10, cis-12 $(\mathrm{P}<0.01)$ and lower proportion of $\mathrm{C} 22: 4 \mathrm{n}-6(\mathrm{P}<0.001)$ in $\mathrm{LD}$. Compared to lambs fed the LC concentrate, those fed the LL concentrate had higher proportions of n-3 PUFA $(P<0.001)$, ALA $(P<0.001)$, EPA $(P<0.001)$ and DPA $(\mathrm{P}<0.01)$, without change in the DHA proportion in LD. The LA/ALA ratio was lower in lambs fed the LL concentrate than in those fed the LC concentrate.

The DM of dorsal AT and the proportions of the ESFA, C14:0, C18:0, C18:1 trans-10, C18:2 trans-10,cis-12 and C20:2 n-6 in dorsal AT were not affected by the experimental concentrates. Compared to lambs fed the LC concentrate, those fed the LL concentrate had lower proportions of $\mathrm{C} 16: 0 \quad(\mathrm{P}<0.05), \quad \mathrm{C} 15: 0 \quad(\mathrm{P}<0.05), \quad \mathrm{C} 17: 0$ $(\mathrm{P}<0.05)$, Odd FA $(\mathrm{P}<0.01)$, iso-BCFA $(\mathrm{P}<0.01)$, anteiso-BCFA $(\mathrm{P}<0.001)$, OBCFA $(\mathrm{P}<0.05)$, total BCFA $(\mathrm{P}<0.01)$, MUFA $(\mathrm{P}<0.01)$, C16:1 n-7 $(\mathrm{P}<0.001), \mathrm{C} 17: 1 \mathrm{n}-8(\mathrm{P}<0.01)$, OLE $(\mathrm{P}<0.001)$ and $\mathrm{C} 18: 1$ cis-11 $(\mathrm{P}<0.01)$ in AT. Compared to lambs fed the LC diets, those fed the LL diets had higher proportions of VA $(P<0.001)$ with the highest value found in the dorsal AT of the EL-LL lambs (significant interaction ewe concentrate $\times$ lamb concentrate). The proportions of LA $(\mathrm{P}<0.05), \mathrm{RA}(\mathrm{P}<0.01), \mathrm{C} 18: 3$ n-6 $(\mathrm{P}<0.001), \mathrm{n}-6$ PUFA $(\mathrm{P}<0.05)$ as well as those of ALA $(\mathrm{P}<0.001)$, EPA $(\mathrm{P}<0.001)$, DPA $(\mathrm{P}<0.01)$ and $n-3$ PUFA $(P<0.001)$ were higher in dorsal AT of lambs fed the LL concentrate compared to lambs fed the LC concentrate. In contrast, the ARA proportion which was lower $(\mathrm{P}<0.001)$ in lambs fed LL. The
IDCLA was lower in the EC-LL and EL-LL groups than in the EC-LC and EL-LC groups $(\mathrm{P}<0.001)$.

\subsection{Relationships between lamb growth performance, fatty acid proportions and fat quality of dorsal adipose tissue}

In order to investigate the relationships between lamb growth performance, fatty acid proportions and fat quality scores of dorsal AT, Pearson correlation coefficients were calculated, and PCA was used. The post-weaning ADG and lamb weight at slaughter were not related to dorsal fat quality (Table 6 ). Fat color score was positively correlated with Odd-FA and BCFA proportions $(r=0.420$ and 0.437 respectively, $\mathrm{P}<0.01)$ and negatively correlated with the sum of $(\mathrm{C} 12: 0+\mathrm{C} 14: 0)(\mathrm{r}=0.405, \mathrm{P}<0.01)$. Fat softness score was positively correlated with BCFA $(\mathrm{r}=0.322, \mathrm{P}<0.05)$ and LA proportions $(\mathrm{r}=0.355, \mathrm{P}<0.05)$ and negatively correlated with ADG before weaning $(\mathrm{r}=-0.444, \quad \mathrm{P}<0.01), \quad(\mathrm{C} 12: 0+\mathrm{C} 14: 0) \quad(\mathrm{r}=-0.486$, $\mathrm{P}<0.01)$ and $\mathrm{C} 16: 0(\mathrm{r}=-0.455, \mathrm{P}<0.01)$ proportions (Table 5$)$. In dorsal AT, the first (PC1) and second (PC2) principal components described $34 \%$ and $22 \%$ of the total variation of data across the 4 treatments. Four clusters of data were identified in the loading plot (Fig. 1). On the PC1, cluster 1 consisting of anteiso-BCFA, OBCFA, Odd FA and fat softness and color scores had loading scores opposite to cluster 2 consisting of $\mathrm{C} 12: 0, \mathrm{C} 14: 0, \mathrm{C} 16: 0$. Cluster 3 including ALA, LA and C18:0 had loading scores opposite to cluster 4 consisting of C16:1 n-7. OLE and IDCLA were associated with the PC2. The loading of the slaughter weight was low, it was therefore discarded from the PCA. 
Table 6

Pearson correlation coefficients between fat quality scores, lamb growth performance and FA composition of dorsal adipose tissue.

\begin{tabular}{|c|c|c|c|c|c|c|c|c|c|c|c|c|}
\hline & ADG post-w & Slaughter Weight & C12-14 & $\mathrm{C} 16: 0$ & C18:0 & Odd-FA & BCFA & MUFA & LA & ALA & Fat color & Fat softness \\
\hline ADG pre-w & 0.568 & 0.078 & 0.508 & 0.175 & -0.281 & -0.014 & -0.068 & 0.190 & -0.207 & 0.207 & -0.264 & -0.444 \\
\hline ADG post-w & & 0.255 & 0.228 & -0.085 & -0.376 & 0.259 & 0.212 & 0.111 & -0.098 & 0.007 & 0.066 & -0.074 \\
\hline Slaughter Weight & & & -0.028 & 0.046 & -0.013 & 0.172 & 0.178 & -0.150 & 0.015 & -0.098 & 0.291 & 0.119 \\
\hline C12-14 & & & & 0.697 & 0.210 & -0.535 & -0.584 & 0.106 & -0.524 & -0.096 & -0.405 & -0.486 \\
\hline $\mathrm{C} 16: 0$ & & & & & 0.148 & -0.390 & -0.442 & 0.147 & -0.523 & -0.341 & -0.217 & -0.455 \\
\hline C18:0 & & & & & & -0.742 & -0.698 & -0.391 & -0.078 & -0.055 & -0.239 & -0.172 \\
\hline Odd-FA & & & & & & & 0.967 & -0.225 & 0.092 & -0.137 & 0.420 & 0.263 \\
\hline BCFA & & & & & & & & -0.270 & 0.075 & -0.164 & 0.437 & 0.322 \\
\hline MUFA & & & & & & & & & -0.342 & -0.416 & -0.122 & 0.025 \\
\hline C18:2 n-6 (LA) & & & & & & & & & & 0.613 & 0.181 & 0.355 \\
\hline C18:3 n-3 (ALA) & & & & & & & & & & & -0.126 & -0.057 \\
\hline Fat color & & & & & & & & & & & & 0.595 \\
\hline
\end{tabular}

Bold $=\mathrm{P}<0.05$, Italic Bold $=\mathrm{P}<0.01$.

ADG pre-w $=$ ADG during the pre-weaning period, post-w = during the post-weaning period.

$\mathrm{C} 12-14=\mathrm{C} 12: 0+\mathrm{C} 14: 0$.

Odd-FA = Odd-numbered FA

$\mathrm{BCFA}=$ Methyl branched chain FA

MUFA = Monounsaturated FA

Fat color: 4 points scale: 1 : very firm to 4 : very soft and oily fat.

Fat softness: 4 points scale: 1 : white to 4 : colored fat.

\section{Discussion}

\subsection{Effect of ewe linseed supplementation on milk composition}

Milk FA composition was determined as an indirect indicator of ALA availability to suckling lambs, reflecting whether ewes were supplemented or not with linseed. Even though ewes were fed only 2 concentrates (EC or EL), statistical analysis of milk FA profiles included the interaction between the effects of the ewe concentrate and the lamb concentrate to better evaluate the relationship between specific FA intake from milk and proportions of FA in lamb tissues. As previously observed (Gomez-Cortes, Bach, Luna, Juarez, \& De la Fuente, 2009; Luna, Fontecha, Juarez, \& De la Fuente, 2005; Mele et al., 2007; Zhang, Mustafa, \& Zhao, 2006), feeding linseed to dairy ewes increased ALA proportion in milk despite the high biohydrogenation of PUFA in the rumen (Glasser et al., 2008). In the present study, when diet linseed proportion increased from $0 \%$ to $2.7 \%$ of DM, the ALA proportion increased 1.5-fold in milk. This is in agreement with Gomez-Cortes et al. (2009) who showed that the ALA proportion increased 3.5-fold when diet linseed proportion increased from 0 to $6 \%$ of DM. In the present study, the milk level of ALA (i.e. $1.3 \%$ of total FA) obtained with extruded linseed intakes of ewes of $90 \mathrm{~g} / \mathrm{d}$ in milk is in the medium range compared to previous studies using linseed supplementation (Gomez-Cortes et al., 2009; Luna et al., 2005; Mele et al., 2007). Higher levels of milk ALA were observed with higher ewe intakes of extruded linseed: milk ALA values of $2.1 \%$, $1.9 \%$ and $2.5 \%$ were found when ewes were fed $210 \mathrm{~g} / \mathrm{d}$ of linseed (Mele et al., 2007), $126 \mathrm{~g} / \mathrm{d}$ and $288 \mathrm{~g} / \mathrm{d}$ of linseed (Delmotte, Rondia, Raes, Dehareng, \& Decruyenaere, 2007) respectively.

LA proportion in milk was decreased by linseed supplementation reflecting lower dietary LA intake of the linseed groups relative to the control groups. Conflicting results from the literature on LA

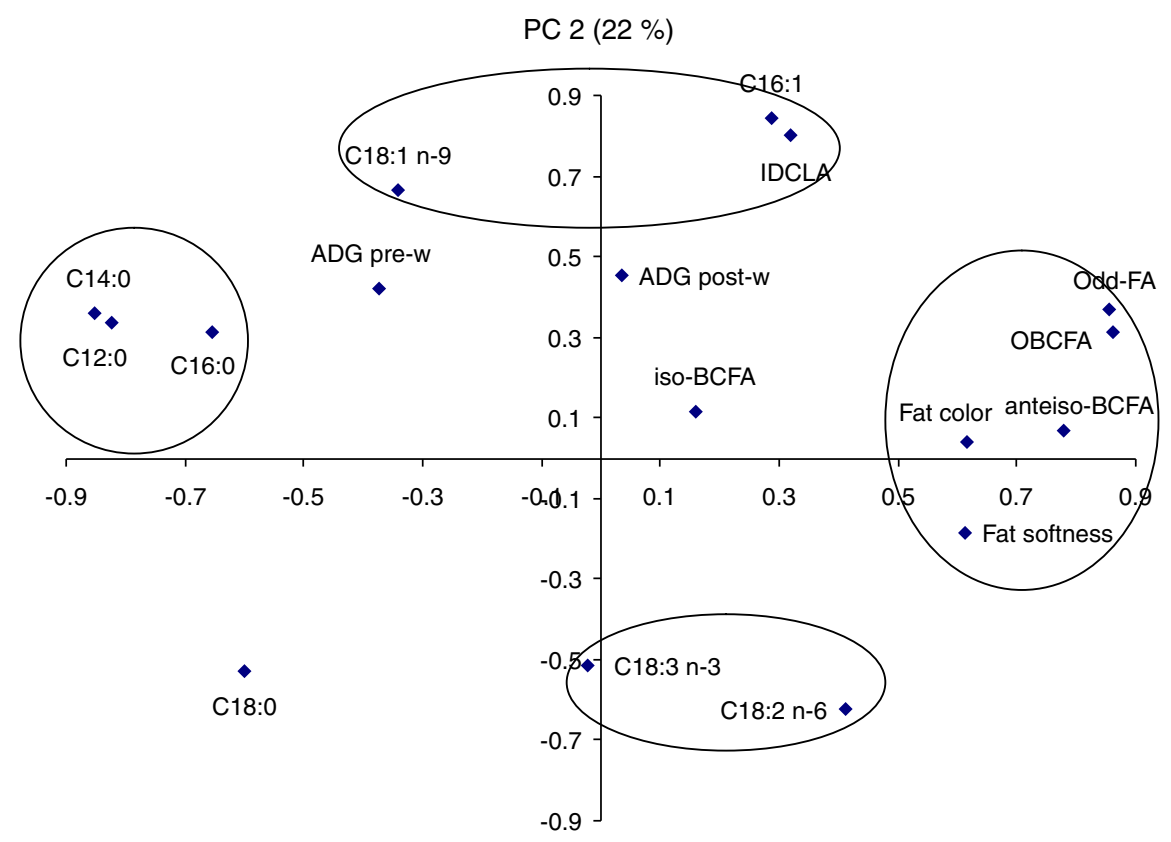

PC $1(34 \%)$

Fig. 1. Principal component analysis loadings between dorsal FA percentage (\% of total FA), growth performance (ADG pre-w=average daily gain before weaning, ADG post$\mathrm{w}=\mathrm{ADG}$ between weaning and slaughter) and the dorsal fat softness and color scores. 
response to linseed supplementation were observed with an increase (Zhang et al., 2006), no change (Gomez-Cortes et al., 2009) or a decrease (Luna et al., 2005) in LA proportion. These results may reflect difference in dietary LA intake. In the present study, ewe linseed supplementation significantly increased the sum of C18:1 trans in agreement with other studies (Gomez-Cortes et al., 2009; Luna et al., 2005). However no increase in milk proportion of VA and C18:1 trans-10 was observed with ewe linseed supplementation contrary to the above mentioned studies. This discrepancy between experiments could be explained either by the difference in dietary forage:concentrate ratios or by the levels of concentrate or lipid intake (Chilliard et al., 2007).

In the present study, a ewe concentrate $\times$ lamb concentrate interaction was significant for short, medium and long-chain saturated FA and for most MUFA (OLE and many C18:1 trans FA) proportions in milk. The ewes of the EC-LL group had a quite different milk profile from other groups, with an increase in short and medium-chain SFA and lower proportions of C18:0, and, cis- and trans-C18:1. Despite no obvious explanation for this, these data are in agreement with the well-known inverse relationship between LCFA uptake and FA synthesis (Chilliard \& Ferlay, 2004).

\subsection{Growth performance and carcass characteristics of lambs}

In the present study, the ADG reached 260-290 g/day and 370$400 \mathrm{~g} /$ day during the pre-weaning and post-weaning periods, respectively, independently of dietary effects; this is in the high range of what is usually observed, which could be due to a good ewe milk production during the pre-weaning period and the high NEg intake due to the concentrate intake during both periods. There was no effect of maternal and lamb linseed supplementations on lamb weaning weight, weight at slaughter, and their ADG during this study. A decrease of lamb ADG $(-12 \%)$ with linseed supplementation was only observed by Delmotte et al. (2007) but as stated by the authors, these lambs had echtyma which is an acute infectious disease reducing gain and feed efficiency in lambs. Otherwise, no detrimental effect of linseed supplementation on growth performance have been reported by most studies on lambs, regardless of the form of seed or oil (Bas et al., 2007; Berthelot et al., 2010; Demirel et al., 2004; Radunz et al., 2009; Wachira et al., 2002). This is in agreement with our results. No effect of linseed supplementation of maternal and lamb concentrates was observed on cold carcass weight and killing out proportion, which agrees with previous studies (Bas et al., 2007; Berthelot et al., 2010; Demirel et al., 2004; Radunz et al., 2009; Wachira et al., 2002).

In the present study, the carcass conformation score was only decreased in lambs that suckled milk from linseed supplemented ewes but that were fed the control concentrate. However no change in their fatness score was measured. Inconsistent results in the literature for the effect of linseed supplementation on conformation and fatness scores have been reported. Lower conformation scores and higher fatness scores have been reported in lambs fed linseed during post-weaning period (Demirel et al., 2004), but no effect of pre-weaning and post-weaning PUFA oil supplementation on lamb conformation and fatness was reported by Radunz et al. (2009). The fat quality scores obtained in the present study were quite high because only male lambs were studied (Busboom et al., 1981). Under high quality market conditions, soft and colored fat (scores 3 and 4) are considered undesirable. However, no decrease of fat firmness was observed with linseed supplementation, in agreement with Bolte, Hess, Means, Moss, and Rule (2002) who fed lambs less unsaturated lipids (high-oleate or linoleate safflower) than in the present study. An improvement of the fat color score was even observed in one of the linseed group supplemented mainly during the post-weaning period (a higher lightness and a lower redness).
4.3. Effect of ewe linseed supplementation and lamb linseed supplementation on muscle and adipose tissue ALA and n-3 PUFA proportion

In the present study, linseed supplementation increased ALA proportion 2.9 and 3.6-fold in muscle and dorsal AT, respectively. FA composition of muscle and adipose tissues in suckling lambs or kids depends on the milk FA profile which is strongly related to the composition of the diet of their dams (Lanza et al., 2006; Napolitano, Cifuni, Pacelli, Riviezzi, \& Girolami, 2002; Nudda et al., 2008). However, in the present study, no benefit of ewe ALA supplementation was obtained on overall ALA proportion in lamb tissues because of a lower increase in milk ALA proportion (1.7-fold) compared to other studies (2.6-fold for Lanza et al. (2006), 2.8-fold for Napolitano et al. (2002), 3-fold for Nudda et al. (2008)). Moreover, in those studies, muscle and adipose tissue FA composition were analyzed on young lambs or kids slaughtered between 30 and 45 days of age (9-11 kg of live weight) with a partially functional rumen. In the present study, lambs were weaned at 76 days of age ( $25 \mathrm{~kg}$ of live weight) and ate non negligible amounts of concentrates during the preweaning period. This might change intramuscular FA profiles due to activation of extensive ruminal biohydrogenation of dietary PUFA as observed by Cifouni, Napolitano, Pacelli, Riviezzi, and Girolami (2000). Feeding lambs with linseed increased the proportion of ALA in tissues but only in the post-weaning period, this is in line of previous trials studying post-weaning linseed supplementation (Bas et al., 2007; Berthelot et al., 2010; Demirel et al., 2004; Wachira et al., 2002). However, contrary to our results, soybean and linseed oils supplementation during the post-weaning period (Radunz et al., 2009) failed to increase ALA proportion in muscle and AT. This discrepancy may reflect differences in ALA intake (estimated $11 \mathrm{~g} / \mathrm{d}$ in Radunz et al., 2009 vs $18 \mathrm{~g} / \mathrm{d}$ in the present study) and/or difference in biohydrogenation processes due to the form of lipid supplementation (oil vs extruded linseed) as suggested by the greater proportion of intermediary biohydrogenation products in subcutaneous AT ( $18.5 \%$ vs $9.9 \%$ of trans-C18:1 in Radunz et al., 2009 vs in the present study respectively). Finally, the greater responses of those tissues to the post-weaning linseed supplementation compared with the pre-weaning linseed supplementation might also reflect differences in timing of FA deposition, with a greater proportion of FA deposition in those tissues occurring after weaning.

In the present study, the supply of ALA in muscle remained rather low, between $20 \mathrm{mg}$ and $60-65 \mathrm{mg}$ of ALA for $100 \mathrm{~g}$ of muscle of the control or linseed supplemented lambs respectively. With respect to the recommended intake of ALA (2 g/d) (EFSA, 2010), it represents $1 \%$ and $3.3 \%$ of the recommended intake. This low ALA level could be due to several factors. First, during the post-weaning period, ALA biohydrogenation ranges between 90 and $95 \%$ (Glasser et al., 2008). Hydrogenation of ALA may be decreased by pH drop in the rumen associated with starch concentrate (Glasser et al., 2008). However, in our conditions, this does not seem to have played a major role on ruminal PUFA biohydrogenation. Secondly, ALA incorporation into muscle neutral lipids and phospholipids is low (Wood et al., 2008). Finally, low ALA proportion in muscle could be due to its lack of competitiveness for incorporation into lipids compared to LA. However, Berthelot et al. (2010), at higher LA and ALA intakes than in the present study, investigated the effect of increasing dietary LA/ALA ratios (from 0.92 to 1.18 , close to our dietary LA/ALA ratio of 0.85 ) on ALA proportion in muscle and demonstrated that this increasing LA availability at high ALA intake had no effect on ALA proportion in tissues. Therefore, competition between LA and ALA on the transfer of ALA to tissue might not explain the low level of ALA in tissues in the present study.

The total muscle n-3 PUFA increment between control and linseed diets was of lower magnitude compared to most studies on linseed supplemented lambs (2.3-fold in the present study) but in agreement 
with our previous study (Berthelot et al., 2010). As generally shown (Berthelot et al., 2010; Demirel et al., 2004; Wachira et al., 2002), but contrary to Bas et al. (2007), a slight increase in EPA ( $+0.15 \%$ of total FA) and DPA ( $+0.10 \%$ of total FA) proportions was observed with linseed supplementation, which confirms the low efficiency of conversion of ALA to LCFA n-3 (Sinclair, 2007). Moreover, no effect of maternal linseed supplementation was observed on these LCFA probably because of its lack of increase in tissue ALA content, ALA being the first step for elongation and desaturation to LCFA n-3. Our results are opposite to those of Radunz et al. (2009) who observed a slight increase in EPA and DPA muscle proportion due to the preweaning oil supplementation period but not to the post-weaning oil supplementation period. This discrepancy may be related to the oil supplementation used during the pre-weaning period in their study based on a mixture of soybean oil and marina algal oil rich in long-chain n-3 PUFA. This supplementation increased the EPA (10-15-fold), DPA (2.5-4-fold), and DHA (28-48-fold) proportion in ewe milk, those FA exhibiting usually negligible proportions in ewe milk (Reynolds, Cannon, \& Loerch, 2006). Yet, in the present study, with respect to the recommended intake of EPA + DHA $(500 \mathrm{mg} / \mathrm{d})(E F S A, 2010)$, the supply of EPA + DHA was still very low, around $10 \mathrm{mg}$ ( $2 \%$ of the recommended intake) or $15 \mathrm{mg}(3 \%)$ for $100 \mathrm{~g}$ of muscle of the control or linseed supplemented lamb respectively.

\subsection{Effect of ewe linseed supplementation and lamb linseed supplementation on muscle and adipose tissue LA, n-6 PUFA, CLA and trans-FA proportion}

Even though the increase in LA intake between linseed supplemented and control lambs was low during the post-weaning period $(+1.84 \mathrm{~g} / \mathrm{d}$ or 1.16 -fold increase), linseed supplementation during this period increased the proportion of LA by 1.18 -fold in both muscle and dorsal AT. Results on the relationship between increasing LA intake and LA proportion in muscle are variable with no relationship (Beaulieu, Drackley, \& Merchen, 2002; Berthelot et al., 2010), or a positive relationship reported (Bessa et al., 2007; Bolte et al., 2002). Moreover, a decrease in C18:3 n-6 proportion in muscle and C20:4 n-6 proportion in dorsal AT was observed without any change in C20:3 n-6 and C20:4 n-6 proportions in muscle. It has already been shown that high ALA availability decreased the conversion of LA to longer n-6 PUFA (Berthelot et al., 2010; Wachira et al., 2002) as both n- 6 and $n-3$ share a common desaturation/elongation pathway. The LA/ALA ratio significantly decreased in muscle with the lamb linseed supplemented concentrate and tended to decrease with the ewe linseed supplementation $(P=0.14)$, which is of nutritional interest.

Feeding lamb linseed supplemented concentrate increased the proportion of VA in lamb muscle and dorsal AT, and the proportion of RA in dorsal AT, in agreement with Wachira et al. (2002) and Berthelot et al. (2010) but contrary to Bas et al. (2007) and Radunz et al. (2009). As RA mainly arises from the $\Delta-9$ desaturase activity on VA in tissues (Palmquist, St-Pierre, \& Mc Clure, 2004), the increase in RA proportion reflects mostly the increase in the production of ruminal VA and therefore the increase in the level of intake of OLE, LA and ALA. Discrepancies between these studies may be due either to differences in the levels of intake of these FA or to different levels of $\Delta-9$ desaturase inhibition by LCFA, as it was shown that $\Delta-9$ desaturase activity is more markedly decreased by oilseed than free oil and by PUFA with increasing inhibition as the degree of FA unsaturation increases (Chilliard, \& Ferlay, 2004). Contrary to our previous study (Berthelot et al., 2010) but in agreement with Bas et al. (2007), linseed supplementation did not increase the proportion of C18:1 trans-10 in muscle or in AT but it slightly increased C18:2 trans-10, cis12 in muscle but not in AT. Differences between experiments could be related to differences in LA intake particularly with high concentrate diet, as usually the $\mathrm{C} 18: 1$ trans-10 and C18:2 trans-10, cis-12 arise mainly from the incomplete biohydrogenation of LA rather than ALA in starchy concentrate diets (Lourenço, Ramos-Morales, \& Wallace, 2010).

\subsection{Effect of ewe linseed supplementation and lamb linseed} supplementation on odd and methyl branched-chain FA proportion in subcutaneous adipose tissue and their relationship to fat softness

In ruminants, most of Odd-FA and of iso and anteiso-BCFA are synthesized by rumen micro-organisms by $\alpha$-oxidation of evennumbered FA or lengthening of the propionate carbon chain for OddFA (Emmanuel, 1978), or from oxidative deamination of branched amino acids for iso and anteiso-BCFA (Duncan \& Garton, 1978). These FA are then absorbed and taken up into the AT by the action of lipoprotein lipase. However, especially in lamb subcutaneous AT, some Odd-FA and BCFA (anteiso-BCFA and OBCFA) are synthesized de novo from propionyl-CoA or methylmalonyl-CoA (the first carboxylation product of propionate) instead of acetyl-CoA (Scaife, Wahle, \& Garton, 1978). In the present experiment, linseed supplementation during post-weaning period decreased the proportion of iso $(-0.13 \%$ of total FA), anteisoBCFA $(-0.37 \%$ of total FA), and of Odd-FA $(-1.35 \%$ of total FA) in dorsal AT in agreement with previous results (Bas et al., 2007, Berthelot et al., 2010, Demirel et al., 2004). For iso-FA it might be, partly or totally, related to the inhibitory effect of PUFA on rumen microbial growth (Doreau, \& Chilliard, 1997). However, in the present study and contrary to the results of Berthelot et al. (2010), linseed supplementation also decreased the proportion of OBCFA $(-1.98 \%$ of total FA) in dorsal AT. The discrepancy between these results might be due to the difference in the analyzed AT (caudal vs dorsal) as dorsal AT is the most sensitive subcutaneous adipose tissue to OBCFA modification with potentially a greater lipogenesis activity (Berthelot, Bas, Schmidely, \& Duvaux-Ponter, 2001). The decreased in OBCFA with linseed supplementation could be due to a reduced FA de novo biosynthesis (Chen, Mao, Ma, \& Liu, 2010; Vernon, 1976).

PCA is an efficient tool to associate changes in fat quality (softness and color) to those in FA profile: the first axis associated softer and more colored fat to Odd-FA, anteiso-FA and OBCFA proportions which was in opposition to even saturated FA proportions, especially medium-chain even saturated FA. This is in agreement with Busboom et al. (1981) except for the C18:0 proportion which was not correlated to fat quality in the present study. On the second PCA axis, PUFA were in opposition to OLE, C16:1 and $\Delta-9$ desaturase index. This might indicate a decrease of the stearoyl-desaturase expression with PUFA supplementation, in agreement with a measured decrease in subcutaneous AT of lamb fed corn oil (Chen et al., 2010). As ALA proportion had a loading score orthogonal to the PC1 axis, it confirmed that, even when lambs were fed diets rich in ALA, softer and more colored AT was directly related to high proportions of Odd-FA and OBCFA and to lower proportions of even-saturated FA. This has already been observed in lambs fed high concentrate diets (Bas, Giral, \& Rouzeau, 1998; Miller, Kunsman, \& Field, 1980; Normand et al., 2005; Orskov, Duncan, \& Carnie, 1975).

\section{Conclusion}

Feeding extruded linseed to lambs during the post-weaning period but not during the pre-weaning period increased the proportion of ALA and long-chain n-3 PUFA in muscle and AT of intensively reared-lambs. The subcutaneous fat color was improved with linseed supplementation with no change in fat softness. Fat color and softness scores were negatively associated with medium even-chain saturated FA, positively associated with Odd-FA and BCFA but not with ALA proportions in subcutaneous AT. 


\section{Acknowledgment}

Funds for this research were provided by the region Limousin. The authors also acknowledge GIE Ovins du Limousin (M. Fourgeaud) and Technopole Viandes du Limousin (S. Brouard) for their support. The people of the experimental farm (Le Mourier) and H. Albarello, L Péricard (UMR 791) are thanked for their technical support and Pr. P. Schmidely for helpful readings and comments.

\section{References}

Aurousseau, B. (1999). The origin of ovine carcass discoloration: A review. Sciences des Aliments, 19, 515-542.

Bas, P., Berthelot, V., Pottier, E., \& Normand, J. (2007). Effect of linseed on fatty acid composition of muscles and adipose tissues of lambs with emphasis on trans fatty acids. Meat Science, 77, 678-688.

Bas, P., Giral, B., \& Rouzeau, A. (1998). Défauts de qualité des gras de couverture des agneaux de race Lacaune élevés en bergerie. In J. C. Flamand, D. Gabina, \& M. Espejo Diaz (Eds.), Proceedings of the International Symposium on basis of the quality of typical Mediterranean animal products (pp. 451-455). Wageningen: EAAP Publication.

Bas, P., \& Morand-Fehr, P. (2000). Effect of nutritional factors on fatty acid composition of lamb fat deposits. Livestock Production Science, 64, 61-79.

Beaulieu, A. D., Drackley, J. K., \& Merchen, N. R. (2002). Concentrations of conjugated linoleic acid (cis-9, trans-11-octadecadienoic acid) are not increased in tissue lipids of cattle fed a high-concentrate diet supplemented with soybean oil. Journal of Animal Science, 80, 847-861.

Berthelot, V., Bas, P., \& Schmidely, P. (2010). Utilization of extruded linseed to modify fatty composition of intensively-reared lamb meat: effect of associated cereals (wheat vs corn) and linoleic content of diet. Meat Science, 84, 114-124.

Berthelot, V., Bas, P., Schmidely, P., \& Duvaux-Ponter, C. (2001). Effect of dietary propionate on intake patterns and fatty acid composition of adipose tissues in lambs. Smal Ruminant Research, 40, 29-39.

Berthelot, V., Normand, J., Bas, P., \& Kristensen, N. B. (2001). Softness and fatty acid composition of subcutaneous adipose tissue, and methylmalonic acid concentrations in the plasma of intensively-reared lambs. Small Ruminant Research, 41, 29-38.

Bessa, R. J. B., Alves, S. P., Jeronimo, E., Alfaia, C. M., Prates, J. A. M., \& Santos-Silva, J. (2007). Effect of lipid supplements on ruminal biohydrogenation intermediates and muscle fatty acids in lambs. European Journal of Lipid Science and Technology, 109, 868-878.

Bolte, M. R., Hess, B. W., Means, W. J., Moss, G. E., \& Rule, D. C. (2002). Feeding lambs high-oleate or high-linoleate safflower seeds differentially influences carcas fatty acid composition. Journal of Animal Science, 80, 609-616.

Busboom, J. R., Miller, G. J., Field, R. A., Crouse, J. D., Riley, M. L., Nelms, G. E., et al. (1981). Characteristics of fat from heavy ram and wether lambs. Journal of Animal Science, 52, 83-91.

Chen, X. J., Mao, H. L., Ma, X. M., \& Liu, J. X. (2010). Effects of dietary corn oil and vitamin E supplementation on fatty acid profiles and expression of acetyl CoA carboxylase and Stearoyl-CoA desaturase gene in Hu sheep. Animal Science Journal, $81,165-171$.

Chilliard, Y., \& Ferlay, A. (2004). Dietary lipids and forages interactions on cow and goat milk fatty acid composition and sensory properties. Reproduction, Nutrition, Development, 44, 467-492.

Chilliard, Y., Glasser, F., Ferlay, A., Bernard, L., Rouel, J., \& Doreau, M. (2007). Diet, rumen biohydrogenation and nutritional quality of cow and goat milk fat. European Journal of Lipid Science and Technology, 109, 828-855.

Cifouni, G. F., Napolitano, F., Pacelli, C., Riviezzi, A. M., \& Girolami, A. (2000). Effect of age at slaughter on carcass traits, fatty acid composition and lipid oxidation of Apulian lambs. Small Ruminant Research, 35, 65-70.

de Andrade, P. V. D., \& Schmidely, P. (2006). Effect of duodenal infusion of trans 10 cis-12-CLA on milk performance and milk fatty acid profiles in dairy goats fed high or low concentrate diet in combination with rolled canola seed. Reproduction, Nutrition, Development, 46, 31-48.

Delmotte, C., Rondia, P., Raes, K., Dehareng, F., \& Decruyenaere, V. (2007). Omega 3 and CLA naturally enhanced levels of animal products: Effects of grass and linseed supplementation on the fatty acid composition of lamb meat and sheep milk. Options Méditerranéennes, Série A, Séminaires Méditerranéen, 74, 41-48.

Demirel, G., Wachira, A. M., Sinclair, L. A., Wilkinson, R. G., Wood, J. D., \& Enser, M. (2004). Effects of dietary n-3 polyunsaturated fatty acids, breed and dietary vitamin $\mathrm{E}$ on the fatty acids of lamb muscle, liver and adipose tissue. The British Journal of Nutrition, 91, 551-565.

Doreau, M., \& Chilliard, Y. (1997). Digestion and metabolism of dietary fat in farm animals. The British Journal of Nutrition, 78(Supplement 1), S15-S35.

Doreau, M., \& Ferlay, A. (1993). Digestion and utilisation of fatty acids by ruminants. Animal Feed Science and Technology, 45, 379-396.

Duncan, W. R. H., \& Garton, G. A. (1978). Differences in the proportion of branchedchain fatty acids in subcutaneous triacylglycerols of barley-fed ruminants. The British Journal of Nutrition, 32, 71-75.

EFSA (European Food Safety Authority) (2010). Scientific opinion on dietary reference values for fats, including saturated fatty acids, polyunsaturated fatty acids, monounsaturated fatty acids trans fatty acids, and cholesterol. EFSA Journal, 8(1641), $1-107$.
Emmanuel, B. (1978). The relative contribution of propionate and of long-chain evennumbered fatty acids to the production of long-chain odd-numbered fatty acids in rumen bacteria. Biochemica Biophysica Acta, 528, 239-246.

Erkkilä, A., De Mello, V. D. F., Risérus, U., \& Laaksonen, D. E. (2008). Dietary fatty acids and cardiovascular disease: An epidemiological approach. Progress in Lipid Research, 47, 172-187.

Folch, J., Lees, M., \& Stanley, G. H. S. (1957). A simple method for the isolation and purification of total lipids from animal tissues. The Journal of Biological Chemistry 226, 497-509.

Glasser, F., Schmidely, P., Sauvant, D., \& Doreau, M. (2008). Digestion of fatty acids in ruminants: A meta-analysis of flows and variation factors: 2 . C18 fatty acids. Animal, 2, 691-704.

Gomez-Cortes, P., Bach, A., Luna, P., Juarez, M., \& De la Fuente, M. A. (2009). Effects of extruded linseed supplementation on n-3 fatty acids and conjugated linoleic acid in milk and cheese from ewes. Journal of Dairy Science, 92, 4122-4134.

Gunstone, F. D., Harwood, J. L., \& Padley, F. B. (1994). The lipid handbook (2nd ed.) London: Chapman and Hall.

Hooper, L., Thompson, R. L., Harrison, R. A., Summerbell, C. D., Ness, A. R., Moore, H. J., et al. (2006). Risks and benefits of omega 3 fats for mortality, cardiovascular disease, and cancer: Systematic review. British Medical Journal, 332, 752-755.

INRA (1989). In R. Jarrige (Ed.), Ruminant nutrition. Recommended allowance and feed table. Paris (France): Institut National de Recherche Agronomique.

ISO (1999). Animal feeding stuffs. Determination of moisture and other volatile matter content. International standard 6496.

ISO (2002). Animal feeding stuffs. Determination of crude ash. International standard 5984

ISO (2004). Animal feeding stuffs. Enzymatic determination of total starch content. International standard 15914.

ISO (2005). Animal feeding stuffs. Determination and calculation of crude protein content. International standard 5983.

L'Estrange, J. L., \& Mulvihill, T. A. (1975). A survey of fat characteristics of lamb with particular reference to soft fat condition in intensively fed lambs. The Journa of Agricultural Science (Camb), 84, 281-290.

Lanza, M., Bella, M., Priolo, A., Bargalla, D., Galofaro, V., Landi, C., et al. (2006). Lamb meat quality as affected by a natural or artificial milk feeding regime. Meat Science, 73, 313-318

Leon, H., Shibata, M. C., Sivakumaran, S., Dorgan, M., Chatterley, T., \& Tsuyuki, R. T. T. (2009). Effect of fish oil on arrhythmias and mortality: Systematic review. British Medical Journal, 338, 2931-2939.

Lourenço, M., Ramos-Morales, E., \& Wallace, R. J. (2010). The role of microbes in rumen lipolysis and biohydrogenation and their manipulation. Animal, 4, 1008-1023.

Luna, P., Fontecha, J., Juarez, M., \& De la Fuente, M. A. (2005). Changes in the milk and cheese fat composition of ewes fed commercial supplements containing linseed with special reference to the CLA content and isomer composition. Lipids, 40 , 445-454.

Malau-Aduli, A. E. O., Siebert, B. D., Bottema, C. D. K., \& Pitchford, W. S. (1997). A comparison of the fatty acid composition of triacylglycerols in adipose tissue from Limousin and Jersey cattle. Australian Journal of Agricultural Research, 48, 715-722.

Mele, M., Serra, A., Conte, G., Pollicardo, A., Del Viva, M., \& Secchiari, P. (2007). Whole extruded linseed in the diet of dairy ewes during early lactation: Effect on the fatty acid composition of milk and cheese. Italian Journal of Animal Science, 6 560-562.

Miller, G. J., Kunsman, J. E., \& Field, R. A. (1980). Characteristics of soft subcutaneous fat in ram lambs fed corn and corn-silage diets. Journal of Food Science, 45, 279-282.

Miwa, T. K., Mikolajzack, K. L., Earle, F. R., \& Wolff, I. A. (1960). Gas chromatographic characterization of fatty acids. Identifications of constants for mono and dicarboxylic methyl esters. Analytical Chemistry, 32, 1729-1742.

Napolitano, F., Cifuni, G. F., Pacelli, C., Riviezzi, A. M., \& Girolami, A. (2002). Effect of artificial rearing on lamb welfare and meat quality. Meat Science, 60, 307-315.

Normand, J., Bas, P., Berthelot, V., \& Sauvant, D. (2005). Relationship between fatty acid composition and softness score of adipose tissue in intensively reared lambs fed with concentrate based on cereals or on beet pulp. Animal Research, 54, 269-282.

Normand, J., Theriez, M., Bas, P., Aurousseau, M., \& Sauvant, D. (1999). Effect of energy source, cereals vs sugar beet pulp, on growth performance and carcass quality of intensively reared lambs. Animal Research, 48, 367-380.

Nudda, A., Palmquist, D. L., Battacone, G., Fancellu, S., Rassu, S. P. G. \& Pulina, G. (2008). Relationship between the contents of vaccenic acid CLA and n-3 fatty acids of goat milk and the muscle of their suckling kids. Livestock Science, 118, 195-203.

Orskov, E. R., Duncan, W. R. H., \& Carnie, C. A. (1975). Cereal processing and food utilization by sheep-3. The effect of replacing whole barley by whole oats on food utilization and firmness and composition of subcutaneous fat. Animal Production, 21, 51-58.

Palmquist, D. L., St-Pierre, N., \& Mc Clure, K. E. (2004). Tissue fatty acid profiles can be used to quantify endogenous rumenic acid synthesis in lambs. The Journal of Nutrition, 134, 2407-2414.

Radunz, A. E., Wickersham, L. A., Loerch, S. C., Fluharty, F. L., Reynolds, C. K., \& Zerby, H. N. (2009). Effects of dietary polyunsaturated fatty acid supplementation on fatty acid composition in muscle and subcutaneous adipose tissue of lambs. Journal of Animal Science, 87, 4082-4091.

Reynolds, C. K., Cannon, V. L., \& Loerch, S. C. (2006). Effects of forage source and supplementation with soybean and marine algal oil on milk fatty acid composition of ewes. Animal Feed Science and Technology, 131, 333-357.

Rule, D. C. (1997). Direct transesterification of total fatty acids of adipose tissue, and of freeze-dried muscle and liver with boron-trifluoride in methanol. Meat Science, 46, $23-32$.

SAS (2002). SAS/STAT 9.1 User's Guide Version (9 Edition). Cary, NC: SAS Institute Incorporated. 
Scaife, J. R., Wahle, K. W. J., \& Garton, G. A. (1978). Utilization of methylmalonate for the synthesis of branched-chain fatty acids by preparations of chicken liver and sheep adipose tissue. The Biochemical Journal, 176, 799-804.

Sinclair, L. A. (2007). Nutritional manipulation of the fatty acid composition of sheep meat: A review. The Journal of Agricultural Science, 145, 419-434.

Vernon, R. G. (1976). Effect of dietary fat on ovine adipose tissue metabolism. Lipids, 11, 662-669.

Vlaeminck, B., Dufour, C., Van Vuuren, A. M., Cabrita, A. R. J., Dewhurst, R. J., Demeyer, D., et al. (2005). Use of odd and branched-chain fatty acids in rumen contents and milk as a potential microbial marker. Journal of Dairy Science, 88, 1031-1042.

Wachira, A. M., Sinclair, L. A., Wilkinson, R. G., Enser, M., Wood, J. D., \& Fisher, A. V. (2002). Effects of dietary fat source and breed on the carcass composition, $n-3$ polyunsaturated fatty acid and conjugated linoleic acid content of sheep meat and adipose tissue. The British Journal of Nutrition, 88, 697-709.

Willett, W., \& Mozaffarian, D. (2008). Ruminant or industrial sources of trans fatty acids: Public health issue or food label skirmish? The American Journal of Clinical Nutrition, 87, 515-516.

Wood, J. D., Enser, M., Fisher, A. V., Nute, G. R., Sheard, P. R., Richardson, R. I., et al. (2008). Fat deposition, fatty acid composition and meat quality: A review. Meat Science, 78, 343-358.

Zhang, R. H., Mustafa, A. F., \& Zhao, X. (2006). Effects of feeding oilseeds rich in linoleic or linolenic fatty acids to lactating ewes on cheese yield and on fatty acids composition of milk and cheese. Animal Feed Science and Technology, 127, 220-233. 